\title{
Association between sociodemographic characteristics and anxiety levels of violence- exposed patients admitted to emergency clinic
}

This article was published in the following Dove Press journal:

Neuropsychiatric Disease and Treatment

26 February 2016

Number of times this article has been viewed

\author{
Hilal Hocagil' \\ Filiz Izci $^{2}$ \\ Abdullah Cüneyt Hocagil' \\ Ebru Findikli ${ }^{3}$ \\ Sevda Korkmaz ${ }^{4}$ \\ Merve Iris $\mathrm{Koc}^{5}$ \\ 'Department of Emergency, School \\ of Medicine, Bulent Ecevit University, \\ Zonguldak, ${ }^{2}$ Department of Psychiatry, \\ School of Medicine, Istanbul Bilim \\ University, Istanbul, ${ }^{3}$ Department of \\ Psychiatry, School of Medicine, Sutcu \\ Imam University, Kahramanmaras, \\ ${ }^{4}$ Department of Psychiatry, School \\ of Medicine, Firat University, Elazig, \\ ${ }^{5}$ Department of Psychiatry, Erenkoy \\ Training and Research Hospital \\ for Psychiatric and Neurological \\ Disorders, Istanbul, Turkey
}

Background: Here we aimed to investigate sociodemographic characteristics, psychiatric history, and association between sociodemographic characteristics and anxiety levels of violenceexposed patients admitted to emergency clinic.

Methods: This study consists of 73 violence-exposed patients admitted to emergency clinic who were literate and agreed to participate in the study. A sociodemographic data form created by us to investigate alcohol-substance abuse, suicide attempt, previous history of trauma, self and family history of psychiatric disorders and Beck Anxiety Inventory was given to the patients. Results: Of the patients exposed to violence $63 \%(n=46)$ were female and $27 \%(n=27)$ were male. Of these patients, $68.5 \%(n=50)$ were married, $43.8 \%(n=25)$ were workers, $34.2 \%$ were housewives, $11 \%$ were unemployed, and $11 \%$ were civil servants. Of the violence-exposed patients, $56.2 \%(\mathrm{n}=41)$ were primary school, $21.9 \%(\mathrm{n}=16)$ were high school, and $21.9 \%(\mathrm{n}=16)$ were university graduates. Smoking and alcohol use rates were $54.8 \%(n=40)$ and $17.8 \%(n=13)$, respectively. The most common trauma type was assault using physical force with a ratio of $78.1 \%(\mathrm{n}=57)$. In addition, anxiety scores were high in $42.5 \%(\mathrm{n}=31)$ and moderate in $9.6 \%$ $(\mathrm{n}=7)$ of the patients. Mentioned psychiatric disorder was present in $17.8 \%(\mathrm{n}=13)$ of the patients and $19.2 \%(n=14)$ of the patients' relatives. The correlation between sociodemographic characteristics and anxiety scores revealed that married patients had higher anxiety scores $(P<0.01)$ and patients assaulted by their parents had lower anxiety scores $(P<0.00)$.

Conclusion: A total of $63 \%$ of the violence-exposed patients admitted to emergency room were females, $56.2 \%$ were primary school graduates, and $43.8 \%$ were factory workers; this result shows that low socioeconomical status and education level affect exposure to trauma especially in females. In addition, $\sim 20 \%$ of the patients and patients' relatives had a psychiatric disorder and $53.4 \%$ of perpetrators were parents, spouses, and children; this result shows that psychiatric history and family relations are one of the issues that should be taken into account and treated. Keywords: violence, emergency, anxiety

\section{Introduction}

Violence is seen as a major health problem in developed countries. The most general definition of violence is behaviors that harm or possibly harm a person physically, sexually, psychologically, or economically or cause pain and all kinds of physical, sexual, psychological, verbal, and economic attitudes and behaviors including threats, pressure, or unnecessary blocking freedom occurring in private or public areas. ${ }^{1}$ Violence can be seen in different forms, including physical violence, psychological (emotional) violence, sexual violence, verbal violence, and economic violence. ${ }^{2}$ The majority of the cases admitted to emergency clinics are physical violence-related injuries. Physi-
Correspondence: Filiz Izci

Department of Psychiatry, School of Medicine, Istanbul Bilim University, Abide-i Hurriyet, Cad. No 164, Istanbul 34100 , Turkey

Tel +902I25054503013

Email filizizci@yahoo.com 
cal violence is defined as hard and painful actions (behaviors such as beating, slapping, punching, kicking, shoving, throat squeezing) directed externally against physical integrity. ${ }^{3}$ Violence may cause consequences, form physical injury, and death. Also, it may cause alcohol and drug addiction, suicide, depression, chronic somatic diseases, and psychiatric disorders such as eating disorders. ${ }^{4}$

Those at greatest risk of violence are women under the age of 30 with children, female children, adolescent girls and women and children from other age groups, the elderly, the disabled, the homeless, refugees, migrants and ethnic minorities. ${ }^{5}$ Similar to our study, in a research investigating the characteristics of violence-exposed patients, the majority of the violence-exposed patients were women aged between 10 and 30 . While women were mainly exposed to domestic violence, men were mainly exposed to street violence by foreigners using cutters and penetrators. ${ }^{6}$ Here we aimed to investigate sociodemographic characteristics, psychiatric, personal, and family histories of violence-exposed patients admitted to emergency clinic and the association between these characteristics and anxiety levels.

\section{Patients and methods Sample}

Our study consisted of 73 patients assaulted by penetrating instruments, firearms, or using physical force who were admitted to emergency clinic, and agreed to participate in the study with a written informed consent.

According to inclusion criteria, patients aged over 18 years, literate, agreed to participate in the study, traumatized by assault, and admitted to emergency clinic of Kartal Education and Research Hospital in Istanbul were included in the study. The study was designed as a prospective study and approval of ethics committee was taken from the Kartal Education and Research Hospital prior to the study.

A structured sociodemographic and clinical data form designed by us according to clinical experience and information obtained from resources considering the purpose of the study and Beck Anxiety Inventory (validity and reliability was conducted for Turkish language) was given to the patients. Psychiatry consultation was made after the patients were stabilized and psychiatric examination and anxiety levels of the patients were recorded after psychiatric evaluation.

\section{Data collection tools}

Sociodemographic and clinical data collection form: This form is completed by the researcher and includes questions regarding the patient's age, sex, marital status, education level, occupational status, income level, type of the assault, previous history of assault, smoking, alcohol, substance and drug use, psychiatric and organic diseases of the patient and family.

Beck Anxiety Inventory: It was developed by Beck et $\mathrm{al}^{7}$ in 1988 due to the need for a scale to distinguish anxiety from depression. It measures the severity of anxiety symptoms. It is a self-report subjective inventory questioning anxiety and somatic symptoms. It has 21 items rated on a 0-3 Likert-type scale. The total score ranges between 0 and 63 . The height of the total score indicates the severity of anxiety symptoms. Scores of 0-9 indicate no-minimal anxiety, 10-18 indicate mild anxiety, 19-29 indicate moderate anxiety, 30-63 indicate severe anxiety. The validity and reliability study for Turkey was performed by Ulusoy et al. ${ }^{8}$

\section{Statistical analysis}

Statistical analyses were performed with SPSS 19.0 software (SPSS Inc., Chicago, IL, USA). Continuous variables are expressed as mean \pm standard deviation and categorical variables as frequency and percent. Continuous variables are compared with the Kruskal-Wallis test and categorical variables are compared using Pearson's chi-square test. A $P$-value of less than 0.05 is considered statistically significant.

\section{Results}

Seventy-three patients who were exposed to assault and admitted to emergency clinic and met the inclusion criteria were included in the study. Mean age of the patients was $32.5+9.8$ years. Of those who were exposed to violence, $63 \%(n=46)$ were female and $37 \%(n=27)$ were male. Of these patients, $68.5 \%(n=50)$ were married, $27.4 \%(n=20)$ were single, $4.1 \%(\mathrm{n}=3)$ were divorced-widowed, $43.8 \%$ $(n=32)$ were workers, $34.2 \%(n=25)$ were housewives, $11 \%$ $(n=8)$ were unemployed, and $11 \%(n=8)$ were civil servants. In terms of education levels, $56.2 \%(\mathrm{n}=41)$ were primary school, 21.9\% $(n=16)$ were high school, $21.9 \%(n=16)$ were junior college-university graduates. In terms of income levels, $41.1 \%$ had no current income at all, $19.2 \%$ had an income less than 750 Turkish Liras (TL), (Table 1).

History of psychiatric disorder was present in $17.8 \%$ $(n=13)$ of violence-exposed patients and 19.2\% $(n=14)$ of the families. Also, history of an organic disease was present in $27.4 \%$ of the violence-exposed patients and $32.9 \%$ of the families. Smoking and alcohol use rates were $54.8 \%(n=40)$ and $17.8 \%(n=13)$, respectively (Table 2$)$. 
Table I Sociodemographic characteristics of the patients

Patients \% $(n=73)$

Age (mean \pm standard deviation)

Sex, $\mathbf{n}(\%)$

Male

Female

Educational status, $\mathbf{n}(\%)$

Primary school

High school

Junior college/university

Marital status, $\mathbf{n}$ (\%)

Married

Single

Divorced-widowed

Occupational status, $\mathbf{n}(\%)$

Worker

Unemployed

Civil servant

Housewife

Income level, $\mathbf{n}$ (\%)

None

$750 \mathrm{TL}$ or less

750-I,500 TL

I,500 TL or more

Abbreviation: TL, Turkish Liras.

The trauma types were as follows: $78.1 \%(\mathrm{n}=57)$ assault by physical force (most common), 11\% by blunt objects, $8.2 \%$ by penetrating instruments, and $2.7 \%$ by firearms. Previous history of trauma was present in $78.1 \%$ by physical force, $6.8 \%$ by penetrating instruments, $6.8 \%$ by verbal violence, $5.5 \%$, by blunt objects, and $2.7 \%$ by firearms. Of perpetrators, $41.1 \%$ were partners-children, $24.7 \%$ were strangers, $15.1 \%$ were friend-neighbor-familiar, $12.3 \%$ were parents, and $6.8 \%$ were second-degree relatives (Table 3).

Table 2 Psychiatric disorder, organic disease history, alcohol use, and smoking rates of patients and their families

\begin{tabular}{ll}
\hline Psychiatric disorder, $\mathbf{n}$ (\%) & \\
Present & $13(17.8)$ \\
Absent & $60(82.2)$ \\
$\begin{array}{l}\text { Psychiatric disorder history in the family, } \mathbf{n}(\%) \\
\text { Present }\end{array}$ & $14(19.2)$ \\
Absent & $59(80.8)$ \\
Organic disease, $\mathbf{n}(\%)$ & \\
Present & $20(27.4)$ \\
Absent & $53(72.6)$ \\
Organic disease history in the family, $\mathbf{n}$ (\%) & \\
Present & $24(32.9)$ \\
Absent & $49(67.1)$ \\
Smoking, $\mathbf{n}$ (\%) & \\
Present & $40(54.8)$ \\
Absent & $33(45.29)$ \\
Alcohol use, $\mathbf{n}(\%)$ & \\
Present & $13(17.8)$ \\
Absent & $60(82.2)$ \\
\hline
\end{tabular}

Table 3 Types of assault and closeness of victims and perpetrators

\begin{tabular}{ll}
\hline $\begin{array}{l}\text { Types of assault at the time of admission, } \mathbf{n}(\%) \\
\text { Firearms }\end{array}$ & $2(2.7)$ \\
Penetrating instruments & $6(8.2)$ \\
Blunt objects & $8(11)$ \\
Physical force & $57(78.1)$ \\
Previous history of trauma, $\mathbf{n}(\%)$ & \\
Firearms & $2(2.7)$ \\
Penetrating instruments & $5(6.8)$ \\
Blunt objects & $4(5.5)$ \\
Physical force & $57(78.1)$ \\
Verbal violence & $5(6.8)$ \\
Closeness of victims and perpetrators, $\mathbf{n}(\%)$ & \\
Parents & $9(12.39)$ \\
Partner and children & $30(41.1)$ \\
Second-degree relatives & $5(6.8)$ \\
Friend-neighbor-familiar & $1 \mathrm{I}(15.1)$ \\
Stranger & $18(24.7)$ \\
\hline
\end{tabular}

Measured anxiety levels were high in $42.5 \%(\mathrm{n}=31)$, moderate in $9.6 \%(n=7)$, and low in $47.9 \%(n=35)$ of the patients. The correlation comparison of sociodemographic characteristics and anxiety scores revealed that married patients had higher anxiety levels $(P<0.01)$ and patients assaulted by their parents had lower anxiety levels $(P<0.00)$ (Table 4).

\section{Discussion}

Physical and mental health consequences of violence affect the individual, the family, and the entire community socially and emotionally. ${ }^{9}$ The most affected group in society are women. Being a woman is a risk factor for exposure to violence. Women are more exposed to violence especially in the first 30 years of life. The mean age of our sample was $32.5+9.8$ years, similar to other studies and the majority of the patients were women. Pregnancy also increases the risk of violence; $20 \%$ of pregnant adolescents and $15 \%$ of pregnant adults are exposed to violence. Women living separately from their husbands have a risk of exposure to violence that is three times higher than divorced women and 25 times higher than married women. In addition, poverty, poor socioeconomic status, low income, alcohol-substance abuse of the husband, presence of mental illness, and history of childhood trauma are factors that increase the risk of violence. ${ }^{10,11}$ In our study, $\sim 50 \%$ of the violence-exposed patients were primary school graduates and $\sim 70 \%$ were either married or had a partner. Majority of the perpetrators were domestic individuals, such as partners or children. In terms of income levels, $41.1 \%$ of the patients were unemployed and $20 \%$ had an income level less than $750 \mathrm{TL}$ per month. According to 
Table 4 The comparison of sociodemographic characteristics and anxiety levels of patients

\begin{tabular}{llll}
\hline $\begin{array}{l}\text { Characteristics of trauma and } \\
\text { perpetrators }\end{array}$ & $\begin{array}{l}\text { Mild (anxiety } \\
\text { score: 10-18) }\end{array}$ & $\begin{array}{l}\text { Moderate (anxiety } \\
\text { score: 19-29) }\end{array}$ & $\begin{array}{l}\text { Severe (anxiety } \\
\text { score: 30-63) }\end{array}$ \\
\hline $\begin{array}{l}\text { Type of trauma, \% } \\
\text { Firearms }\end{array}$ & 2.9 & 14.3 & 0 \\
Penetrating instruments & 2.9 & 14.3 & 12.9 \\
Blunt objects & 8.6 & 14.3 & 12.9 \\
Physical force & 85.7 & 57.1 & 74.2 \\
History of previous trauma, \% & & & 14.3 \\
Firearms & 2.9 & 0 & 0 \\
Penetrating instruments & 2.9 & 0 & 12.9 \\
Blunt objects & 5.7 & 85.7 & 6.5 \\
Physical force & 80.0 & 0 & 74.2 \\
Verbal violence & 8.6 & & 6.5 \\
Perpetrators, \% & & 0 & 0 \\
Parents & $25.7 *$ & 14.3 & $58.1 * *$ \\
Partners/children & 31.4 & 0 & 9.7 \\
Second-degree relatives & 5.7 & 42.9 & 16.1 \\
Friend-neighbor-familiar & 8.6 & 42.9 & 16.1 \\
Stranger & 28.6 & & \\
\hline
\end{tabular}

Notes: $* p<0.00, * * p<0.01$.

our study, rates of violence exposure were higher in patients with no or low income. Also, history of psychiatric disorder was present in $32.9 \%$ of the patients and $20 \%$ of the families. In terms of smoking and alcohol use, $54.8 \%$ of the patients were smokers and $17.8 \%$ were alcohol users.

Similarly, in our study, patients exposed to violence by their partners and children were mostly women. The most common type of violence was using physical force. Using physical force is using brute force to frighten and intimidate someone. It is the most common form of domestic violence. There is statistical evidence that often women are exposed to physical violence. ${ }^{11}$ According to our study, $\sim 80 \%$ of the patients admitted to emergency were exposed to violence using physical force and majority of these patients were women. In 2001, one-fourth of violent crimes transferred to police in Canada were against women and two-thirds of these were performed by husbands or ex-husbands. ${ }^{12}$ A study conducted in Kenya showed that $42 \%$ of women were regularly exposed to violence by their husbands. ${ }^{13}$ Some of the research conducted in America showed that 20\%-35\% of women were exposed to partner abuse throughout their lives. ${ }^{14}$ Health risks are severe; every day, four women are murdered by their partners and $10 \%-25 \%$ of emergency department visits are due to partner abuse. ${ }^{14}$ A previous study shows lifetime prevalence of partner violence among primary care patients to be around $40 \% .{ }^{14} \mathrm{In}$ a study, 217 of 1,550 patients admitted to emergency clinic were violence-exposed patients and 27 of these cases were domestic violence. ${ }^{15}$ In a study similar to ours, only $11.4 \%$ of the patients admitted to the emergency department stated that they were exposed to violence; however, emergency physicians identified violence in $25 \%$ of the patients. While male patients were exposed to society violence, female patients were exposed to domestic violence. The majority of patients were women living separately from their partners. ${ }^{16}$ In a 10 -year retrospective study in Hong Kong with violence victims admitted to the emergency clinic, $12.9 \%$ were partner-violence victims, $12.8 \%$ were child-abuse victims, and $8.9 \%$ were elderly-abuse victims. ${ }^{17}$ In another study, 3,338 adolescents aged between 16 and 18 were followed up for 36 months and 190 of these adolescents were admitted to emergency clinic for assault-related injuries and most of them were found to have left home. In addition, 160 of them were exposed to aggression and 106 of them were exposed to assault-related injuries during the previous year. Female patients were more likely than male patients to be exposed to violence, have depressive symptoms and leave home. Alcohol-substance abuse and weapon carrying rates were similar among the two groups. ${ }^{18}$ In our study, the mean age was 32.5 years and the majority of the violence-exposed patients were women. Also more than $50 \%$ of the perpetrators were parents, partners, or children. Psychiatric disorder and alcohol use rates were $17.8 \%$ and $32.9 \%$, respectively.

In a study conducted in Switzerland with $\sim 422$ violenceexposed patients admitted to emergency clinic, mean age was 31 years and $57 \%$ of these patients were female and $43 \%$ were male. A total of $90 \%$ of male patients were exposed to society violence and $70 \%$ of women were exposed to domestic violence. Majority of the men were exposed to 
violence by foreigners, however, perpetrators of men's violence against women were mostly partners or ex-husbands. A total of $80 \%$ of women and $47 \%$ of men had a previous history of exposure to violence. ${ }^{19}$ In our study, exposure to violence was higher among women with a rate of $63 \%$. Of perpetrators, $41.1 \%$ were partners-children, $24.7 \%$ were strangers, and $12.3 \%$ were parents. Hence, rate of domestic violence was $\sim 55 \%$.

In a 3-month study of violence-exposed patients admitted to emergency clinic, $\sim 15 \%$ were exposed to domestic violence and $75 \%$ were female. Also, two-thirds of women were exposed to violence by their ex-husbands. A total of $80 \%$ of the victims were under the age of 40 and one-third of the patients had consumed alcohol. ${ }^{20}$ In a study examining emergency clinic admission rates of 1,441 substance-use patients within last 6 months, no violence was reported in $46.8 \%$, partner violence was reported in $17.3 \%$, nonpartner violence was reported in $20.2 \%$, and both partner and nonpartner violence was reported in $15.7 \%$ of the patients. ${ }^{21}$ In our study, mean age and rates of violence among women were similar and $17.8 \%$ of the victims had a history of alcohol use.

In a study investigating 829 primary care patients, it was found that the majority of the violence-exposed patients were women, the most common violence type was psychological and physical violence and the majority of the perpetrators were partners. Also the majority of the victims were unemployed and alcohol users. In this study with patients taking primary care, female sex was found to be a risk factor for domestic violence. ${ }^{22}$ In our study, $~ 30 \%$ of our patients had a history of an organic disease. Again, similarly, $17.8 \%$ of our study group were patients with alcohol use and more than $50 \%$ were unemployed or had a low income level.

According to literature, $49.7 \%$ of the violence-exposed victims had low educational status and $53.7 \%$ of the victims were exposed to domestic violence. ${ }^{23}$ In our study group, $56.2 \%$ of the victims were primary school graduates and more than $50 \%$ were exposed to domestic violence.

\section{Study limitations}

The limitations of our study were lack of a control group, small number of study sample, the low socioeconomic status of patients admitting to this hospital, and the study sample not precisely reflecting the general population.

\section{Conclusion}

According to our findings from the study population, patients exposed to violence were mostly women, have low income level, low educational status also, psychiatric disorders were usually present both in the victim and the perpetrator; hence, we think that these are important variables that need to be considered. Also, majority of the perpetrators were partners or children and patients exposed to violence by their partners had higher anxiety levels, which may indicate a higher frequency of anxiety symptoms in this group of patients. On the other hand, we found that patients exposed to violence by their parents were found to have lower anxiety levels, which may suggest that ongoing domestic violence from childhood might have become a more tolerated situation. Also, presence of psychiatric diagnoses, organic disease histories, alcohol use, smoking and family history of psychiatric disorders in patients exposed to violence may suggest a benefit in reviewing the predictors of violence again. We believe that controlled, randomized studies with bigger samples may provide further contributions to literature.

Female sex, low education level, low income, history of psychiatric disorder in the victim and family can be seen as determining factors of exposure to violence. Also, majority of the perpetrators being partners and children and anxiety levels of patients exposed to violence by their partners being high may suggest that domestic violence is more common and more often causes psychiatric disorders. Lower anxiety levels in patients exposed to violence by their parents may indicate that domestic violence since childhood is a conventional and tolerated condition.

\section{Disclosure}

The authors report no conflicts of interest in this work.

\section{References}

1. Tatlioglu Kasım. Türkiye'de aile içi kadına yönelik şiddetin psikolojik ve sosyal dinamiklerinin değerlendirilmesi. [Evaluation of the psychological and social dynamics of domestic violence against women in Turkey.] Nişantaşı Üniversitesi, Sosyal Bilimler Dergisi. 2013;1(1):129-149. Turkish.

2. Ünlüsoy Dinç N. Hemşirelerin işyeri şiddetine maruz kalma durumları ile iş doyumları ve ișten ayrılma eğilimleri. Doktora Tezi. [Exposure to workplace violence situation and job satisfaction of nurses and redundancy trends. Doctorate Thesis.] Hacettepe Üniversitesi Sağlık Bilimleri Enstitüsü (Hacettepe University Institute of Health Sciences) Ankara; 2010. Turkish.

3. Sağlık çalışanlarına yönelik artan şiddet olaylarının araştırılarak alınması gereken önlemlerin belirlenmesi amacıyla kurulan meclis araştırması komisyonu raporu. Türkiye Büyük Millet Meclisi. Ocak 2013; Yasama Dönemi:24; Yasama Yı11:3; Sıra Sayıs1: 454 [Health research council established for the employees of the escalating violence in order to determine the measures to be taken to investigate the commission report. Grand National Assembly of Turkey. January 2013; Legislative Term: 24; Legislative Year: 3; Sequence Number: 454]. Available from: http:// www.academia.edu/3654719/. Accessed May 22, 2015.

4. Walton MA, Murray R, Cunningham RM, et al. Correlates intimate partner violence among men and women in an inner city emergency department. J Addict Dis. 2009;28(4):366-381. 
5. Barnett OW, Lee CY, Thelen RE. Gender differences in attributions of self-defense and control in interpartner aggression. Violence Against Women. 1997;3(5):462-468.

6. Tingne CV, Shrigiriwar MB, Ghormade PS, Kumar NB. Quantitative analysis of injury characteristics in victims of interpersonal violence: an emergency department perspective. J Forensic Leg Med. 2014;26: 19-23.

7. Beck AT, Epstein N, Brown G, Steer RA. An inventory for measuring clinical anxiety: psychometric properties. J Consult Clin Psychol. 1988; 56:893-897.

8. Ulusoy M, Şahin N, Erkmen H. Turkish version of Beck anxiety inventory: psychometric properties. J Cognit Psychother. 1998;12(2): 163-172.

9. WHO Department of Gender, Women and Health, Family and Community Health. Addressing Violence against Women and Achieving the Millennium Goals. Geneva: World Health Organization; 2005.

10. Wang S, An L, Cochran SD. Women's health. In: Detels R, McEven J, Beaglehole R, Taraka H, editors. Oxford Textbook of Public Health. London: Oxford University Press; 2002:2-90.

11. Meit SS, Fitzpatrick KM, Selby JB. Domestic violence: intimate partner violence. In: Rakel RE, editor. Textbook of Family Medicine. 7th ed. Philadelphia: Saunders Elsevier; 2007:47-67.

12. Subaşı N, Akın A. Kadına yönelik şiddet; nedenleri ve sonuçları [Violence against women; its causes and consequences]. In: Akın A, editor. Toplumsal cinsiyet, sağlık ve kadın. Ankara: Hacettepe Üniversitesi Yayınlar1; 2003:231-247. Turkish.

13. Bilgel N, Orhan H. Aile içi şiddet. [Domestic violence.] In: Bilgel N, editor. Aile hekimliği. (Family Medicine.) Bursa: Medikal Tıp Kitabevi; 2006:643-655. Turkish.

14. Gawinski B, Ruddy N. Ailenin korunması: aile içi şiddet ve birinci basamak hekimi. [Protection of the family: family violence and primary care physicians] (Translator: Dagdeviren HN). McDaniel SH, Campbell TL, Hepworth J, Lorenz A, editors. Aile yönelimli birincil bakım. [Familyoriented primary care.] Istanbul: Yüce Yayım; 2005:99-377. Turkish.
15. Davis JW, Parks SN, Kaups KL, Bennink LD, Bilello JF. Victims of domestic violence on the trauma service: unrecognized and underreported. J Trauma. 2003;54(2):352-355.

16. Hofner MC, Python NV, Martin E, Gervasoni JP, Graz B, Yersin B. Prevalence of victims of violence admitted to an emergency department. Emerg Med J. 2005;22(7):481-485.

17. Chan KL, Choi WM, Fong DY, Chow CB, Leung M, Ip P. Characteristics of family violence victims presenting to emergency departments in Hong Kong. J Emerg Med. 2013;44(1):249-258.

18. Ranney ML, Whiteside L, Walton MA, Chermeck ST, Zimmerman MA, Cunningham RM. Sex differences in characteristics of adolescents presenting to the emergency department with acute assault-related injury. Acad Emerg Med. 2011;18(10):1027-1035.

19. Hofner MC, Burquier R, Huissoud T, Romain N, Graz B, Mangin P. Characteristics of victims of violence admitted to a specialized medicolegal unit in Switzerland. J Forensic Leg Med. 2009;16(5):269-272.

20. Burkert NT, Rásky É, Freidl W, et al. Female and male victims of violence in an urban emergency room - prevalence, sociodemographic characteristics, alcohol intake, and injury patterns. Wien Klin Wochenschr. 2013;125(5-6):134-138.

21. Chermack ST, Murray R, Kraus S, et al. Characteristics and treatment interests among individuals with substance use disorders and a history of past six-month violence: findings from an emergency department study. Addict Behav. 2014;39(1):265-272.

22. Selic P, Pesjak K, Kersnik J. The prevalence of exposure to domestic violence and the factors associated with co-occurrence of psychological and physical violence exposure: a sample from primary care patients. BMC Public Health. 2011;11:621.

23. Rada C. Violence against women by male partners and against children within the family: prevalence, associated factors, and intergenerational transmission in Romania, a cross-sectional study. BMC Public Health. 2014; $14: 129$.
Neuropsychiatric Disease and Treatment

\section{Publish your work in this journal}

Neuropsychiatric Disease and Treatment is an international, peerreviewed journal of clinical therapeutics and pharmacology focusing on concise rapid reporting of clinical or pre-clinical studies on a range of neuropsychiatric and neurological disorders. This journal is indexed on PubMed Central, the 'PsycINFO' database and CAS,

\section{Dovepress}

and is the official journal of The International Neuropsychiatric Association (INA). The manuscript management system is completely online and includes a very quick and fair peer-review system, which is all easy to use. Visit http://www.dovepress.com/testimonials.php to read real quotes from published authors. 